\title{
TES STANDAR DAN NON TES STANDAR
}

\author{
Supandi Supandi ${ }^{1}$, Khodijah Khodijah ${ }^{2}$, Muhammad Arsyam ${ }^{3}$
}

\begin{abstract}
${ }^{1}$ Sekolah Tinggi Agama Islam (STAI) Darul Dakwah Wal-Irsyad (DDI) Kota Makassar, Indonesia Email:Supandiyahudiyahwe66@gmail.com

${ }^{2}$ Sekolah Tinggi Agama Islam (STAI) Darul Dakwah Wal-Irsyad (DDI) Kota Makassar, Indonesia Email: ummuabdullaah2411@gmail.com

${ }^{3}$ Sekolah Tinggi Agama Islam (STAI) Darul Dakwah Wal-Irsyad (DDI) Kota Makassar, Indonesia

Email: arsyam0505@gmail.com
\end{abstract}

\section{Abstrak}

Pendidikan sangat penting bagi kehidupan manusia sehingga harus dipenuhi dan dilakukan untuk meningkatkan kualitas hidup manusia. Maka dari itu untuk melihat hasil atau kemajuan dari pendidikan tersebut diperlukan evaluasi dan penilaian untuk menjadi tolak ukur apakah pendidikan tersebut mendapatkan hasil yang baik atau kurang baik. Evaluasi dan Penilaian harus dilakukan oleh suatu lembaga pendidikan, tetapi evaluasi dan penilaian ini memiliki administrasi yang harus diikuti oleh suatu lembaga pendidikan. Artikel ini menjelaskan dengan jelas mengenai administrasi evaluasi dan penilaian dalam pendidikan meliputi definisi,tujuan,fungsi,ruang lingkup,dan sasaran.

\section{Kata Kunci: Evaluasi, Tes Standar, Non Standar}

\section{A. PENDAHULUAN}

Pendidikan adalah suatu usaha sadar dan terencana untuk mewujudkan suasana belajar dan proses pembelajaran agar peserta didik secara aktif aktif mengembangkan potensi dirinya untuk memiliki kekuatan spiritual keagamaan, pengendalian diri, kepribadian, kecerdasan, akhlak mulia, serta keterampilan, yang diperlukan dirinya, masyarakat, bangsa, dan negara. Pendidikan Nasional adalah pendidikan yang berdasarkan pancasila dan Undang-Undang Dasar Negara Republik Indonesia Tahun 1945 yang berakar pada milai-nilai Agama, kebudayaan, Nasional Indonesia dan tanggap terhadap tuntutan perubahan zaman.

Tes berasal dari bahasa latin testum yang berarti alat untuk mengukur tanah. Dalam bahasa Perancis kuno, kata tes berarti ukuran yang dipergunakan untuk membedakan antara emas dan perak serta logam lainya. Dalam Encyclopedia of Educational Evaluation, tes diartikan; any series of questions or execise or other means of measuring the skill, knowledge, intellegence, capacities or aptitudes of an individual or group. Jadi pada dasarnya tes itu adalah: "pertanyaanpertanyaan yang harus dijawab dan atau perintah-perintah yang harus dijalankan, yang mendasarkan harus bagaimana testee menjawab pertanyaan-pertanyaan atau melakukan perintahperintah itu, penyelidik menggambil kesimpulan dengan cara membandingkan dengan tes standar atau testee lainya”. 


\section{B. PEMBAHASAN}

\section{Pengerian Tes Standar}

Tes standar adalah suatu tes dimana semua siswa menjawab pertanyaan-pertanyaan yang sama dari sebagian besar pertanyaan dikerjakan dengan mengikuti petunjuk yang sama dan dalam batasan waktu yang sama pula. Tes prestasi standar adalah suatu tes yang memenuhi suatu persyaratan validitas, reliabilitas, kepraktisan dan lainnya.Tes standar umunya dibuat oleh suatu tim (guru, ahli psikologi, ahli bidang studi) yang sebelum diteskan, diuji dahulu validitas, reabilitas, kepraktisan dan daya bedanya.

Penyusunan tes standar selalu mengusahakan agar sistem skoringnya sangat obyektif sehingga dapat diperoleh reliabilitas yang sangat tinggi.Apabila mungkin dilakukan oleh mesin,hal ini tidak berarti bahwa bentuk tes standar selalu pilihan ganda. Pengertian tes standar secara sempit adalah tes yang disusun oleh satu tim ahli, atau disusun oleh lembaga yang khusus menyelenggarakan secara professional. Tes tersebut diketahui memenuhi syarat sebagai tes yang baik; yakni diketahui validitas dan reliabilitasnya baik validitas rasional maupun validitas empirik, reliabilitas dalam arti teruji tingkat stabilitas, maupun homoginitasnya.

Tes ini dapat digunakan dalam waktu yang relatif lama, dapat diterapkan pada beberapa obyek mencakup wilayah yang luas.Untuk mengukur validitas dan reliabilitasnya telah diujicobakan beberapakali sehingga hasilnya dapat dipertanggung jawabkan.

Prosedur yang digunakan untuk menyusun tes standar untuk tes prestasi secara langsung yang ditumbuhkan dari tes yang digunakan dikelas. Sedangkan spesifikasi yang digunakan untuk menentukan isi dalam tes bakat biasanya didasarkan atas analisis job(jabatan) atau analisis tugas yang merupakan tuntutan calon pekerjaannya. Disamping itu juga mempertimbangkan sifat-sifat yang ada pada manusia.Analisis jabatan analisis tugas yang dilakukan biasanya tidak tidak didasarkan atas satu kurikulum, tetapi diambil dari masyarakat.

Pengertian tes standar secara sempit adalah tes yang disusun oleh satu tim ahli, atau disusun oleh lembaga yang khusus menyelenggarakan secara professional. Tes tersebut diketahui memenuhi syarat sebagai tes yang baik. Tes ini dapat digunakan dalam waktu yang relatif lama, dapat diterapkan pada beberapa obyek mencakup wilayah yang luas. Untuk mengukur validitas dan reliabilitasnya telah diuji-cobakan beberapa kali sehingga hasilnya dapat dipertanggungjawabkan. 
Tes standar adalah tes yang telah dicobakan berkali-kali sehingga dapat dijamin kebaikannya. Tes yang baik adalah tes yang memiliki validitas, reabiltas, objektivitas, praktikabilitas, dan ekonomis. seperti yang diketahui bahwa tes kemampuan pada dasarnya dibagi menjadi 2 macam, yaitu:

1) Aptitude test (tes bakat);

2) Achievement tes (tes prestasi).

Bakat seseorang dapat diukur dengan tes bakat. Tes bakat adalah tes yang dirancang untuk mengukur kemampuan potensial seseorang dalam suatu jenis aktivitas dispesialisasikan dan dalam rentangan tertentu. Tes bakat adalah tes kemampuan khusus disebut juga tes perbedaan individual, tes yang terpisah (separated test). Karena bakat menunjukkan keunggulan atau keistimewaan kemampuan khusus tadi, maka tes bakat dapat juga disebut tes kemampuan (power ability test) atau disebut differential aptitude test. Sedangkan achievement tes (tes prestasi) dimaksudkan untuk mengukur apa yang telah dipelajari atau keahlian yang telah dikuasai.

Perbedaan antara kedua tes ini sebenarnya tidak tegas, soal-soal mengenai kedua tes tersebut seringkali saling melingkupi (overlap). Untuk kedua macam tes ini biasanya menggunakan hitungan-hitungan dan perbendaharaan kata-kata dan sekelompok tes dari kedua macam tes ini biasanya juga menguki tentang keterampilan membaca. Kesamaan yang lain adalah bahwa keduanya telah digunakan untuk meramalkan hasil untuk masa yang akan datang, walaupun pada umumnya jika kita menggunakan tes prestasi penilai melihat apa yang telah diperoleh setelah siswa (tercoba) itu diberi suatu pelajaran.

Prosedur yang digunakan untuk menentukan isi dari tes prestasi juga sedikit berbeda dengan yang digunakan pada waktu penyusunan tes bakat. Di dalam penyusunan tes prestasi belajar usaha-usaha digunakan untuk menentukan pengetahuan dan keterampilan yang sudah diajarkan diberbagai tingkat pendidikan dan butir-butir tes diperuntukkan bagi penilaian materimateri.

\section{Tes Prestasi Standar}

Diantara tes prestasi yang digunakan di sekolah ada yang dinamakan tes prestasi standard. Dalam salah satu kamus, arti kata "standard" adalah: "a degree of level of requirement, excellence, or attainment” Menurut Kamus Besar Bahasa Indonesia standar diartikan sebagai ukuran tertentu yg dipakai sbg patokan, ukuran atau tingkat biaya hidup, sesuatu yg dianggap tetap nilainya sehingga dapat dipakai sbg ukuran nilai. Sedangkan menurut wikipedia Standar atau 
lengkapnya standar teknis adalah suatu norma atau persyaratan yang biasanya berupa suatu dokumen formal yang menciptakan kriteria, metode, proses, dan praktik rekayasa atau teknis yang seragam.

Standard untuk siswa dapat dimaksudkan sebagai suatu tingkat kemampuan yang harus dimiliki bagi suatu program tertentu. Mungkin standard bagi suatu kursus A berbeda dengan kursus B. Jadi tes standard ini dapat dibuat "keras" maupun "lunak" tergantung dari yang mempunyai kebijaksanaan.

Suatu tes standard dengan demikian berbeda dengan tes prestasi biasa. Prosedur yang digunakan untuk menyususn tes standard untuk tes prestasi melalui cara langsung yang ditumbuhkn dari tes yang digunakan dikelas. Sedangkan spesifikasi yang digunakan untuk menentukan isi dalam tes bakat biasanya didasarkan atas analisa job (jabatan) atau analisa tugas yang merupakan tuntunan calon pekerjanya. Disamping itu juga mempertimbangkan sifat-sifat yang ada pada manusia. Analisa jabatan analisa tugas yang dilakukan biasanya tidak didasarkan atas salah satu kurikulum, tetapi diambil dari masyarakat.

Istilah "standard" dalam tes dimaksudkan hanya bahwa semua siswa menjawab pertanyaan-pertanyaan yang sama dari sejumlah besar pertanyaan dikerjakan dengan mengikuti petunjuk yang sama dan dalam batasan waktu yang sama pula. Dengan demikian maka seolaholah ada suatu standard atau ukuran sehingga diperoleh suatu standard penampilan (performance), dan penampilan kelompok lain dapat dibandingkan dengan penampilan kelompok standard tersebut.

Istilah "standard" tidak mengandung arti bahwa tes itu mengukur apa yang harus dan dapat diajarkan pada suatu tingkat tertentu tau bahwa tes itu menyiapakan suatu standard prestasi dimana siswa harus dan dapat mencapai suatu tingkat tertentu. Sekali lagi, tes standard dipolakan untuk penampilan prestasi sekarang (yang ada) yang dilaksanakan secara seragam, diusahakan dalam kondisi yang seragam baik itu diberikan kepada siswa dalam pelaksanaan perseorangan maupun siswa sebagai anggota dari suatu kelompok.

Penyususnan tes standard selalu mengusahakan agar sistem skoringnya sangat obyektif sehingga dapat diperoleh reabilitas yang tinggi. Apabila mungkin, dilakukan dengan mesin, hal ini tidak berarti bahwa bentuk tes standard harus selalu pilihan berganda. Tetapi untuk skoringnya diusahakan agar tidak kena bias faktor-fator lain. Usaha lain adalah penggunaan 
skala skor dan norma yang relevan. Skala skor digunakan untuk menyesuaikan antara bentuk paralel dan bentuk aslinya. Disamping itu juga diperlukan, penjeleasan terperinci tentang tes ini.

Adapun bentuk tes standard sebagai berikut:

\begin{tabular}{|l|}
\hline \multicolumn{1}{|c|}{ Tes Standard } \\
\hline 1). Didasarkan atas bahan dan tujuan umum dari sekolah diseluruh negara. \\
\hline $\begin{array}{l}\text { 2). Mencakup aspek yang luas dan pengetahuan atau keterampilan dengan hanya sedikit butir } \\
\text { tes untuk setiap keterampilan atau topik. }\end{array}$ \\
\hline 3). Disusun dengan kelengkapan staf: profesor, pembahas, editor butir tes. \\
\hline $\begin{array}{l}\text { 4). Menggunakan butir-butir tes yang sudah diuji cobakan (tryout), dianalisa dan direvisi } \\
\text { sebelum menjadi tes. }\end{array}$ \\
\hline 5). Mempunyai reabilita yang tinggi. \\
\hline 6). Dimungkinkan menggunakan norma untuk seluruh negara. \\
\hline $\begin{array}{l}\text { 7). Dalam penyusunanya dibutuhkan waktu yang lama karena harus melewati beberapa } \\
\text { prosesur dan pengujian. }\end{array}$ \\
\hline 8). Memiliki tingkat pertanggungjawaban yang tinggi. \\
\hline $\begin{array}{l}\text { 9). Anggaran atau biaya pembuatan tes dinaungi oleh pemerintah secara nasional dengan biaya } \\
\text { yang lebih besart. }\end{array}$ \\
\hline 10). Memiliki kegunaan yang mencakup hal yang luas (nasional). \\
\hline
\end{tabular}

Jadi untuk menyusun tes standard, dibutuhkan waktu yang lama. Seperti disebutkan bahwa untuk memperoleh sebuah tes standard dilalui prosedur: Penyusunan, Uji-coba, Analisa, Revisi, Edit, oleh karena itu dari ke lima kegiatan ini membutuhkan waktu lama.

\section{Pengetian Tes Non Standar}

Tes non standard adalah kebalikan tes standar, yaitu tes yang disusun oleh seorang pendidik yang belum memiliki keahlian professional dalam penyusunan tes, atau mereka yang memiliki keahlian tetapi tidak sempat menyusun tes secara baik, mengujicobakan, melakukan analisis sehingga validitas dan reliabilitas belum dapat dipertanggungjawabkan. Tes non standar sering digunakan untuk menyebut tes buatan guru, artinya disusun oleh seorang guru tanpa bantuan tim ahli. Sebenatnya penggunaan istilah kedua ini tidak tepat, sebab mendiskripsikan guru seagai orang yang tidak mampu menyusun tes yang baik, penulis lebih cenderung menggunakan pengertian yang mendasarkan pada kriteria kualitatif dari pada dilihat dari siapa yang menyusun.

Tes buatan guru memang memiliki beberapa kekhususan, bisa jadi syarat kualitatif belum terpenuhi, tetapi ia memiliki kelebihan lebih cocok untuk mengukur hal-hal khusus yang tidak dapat distandarisasikan; seperi formatif, tes diagnostik, hasilnya lebih realistik. Sebab tes ini dirancang sesuai dengan keadan peserrta didik, PBM suatu tingkat dan lembaga pendidikan tertentu. 


\section{Menilai Tes Non Standar}

Dalam proses penilain tes non standar memiliki empat cara untuk menilai tes yaitu :

a. Cara pertama meneliti secara jujur soal-soal yang sudah disusun, kadang-kadang dapat diperoleh jawaban tentang ketidakjelasan perintah atau bahasa, taraf kesukaran, dan lain-lain keadaan soal tersebut. Adapun pertanyaan-pertanyaan tersebut, antara lain:

- Apakah banyaknya soal untuk tiap topik sudah seimbang?

- Apakah semua soal menanyakan bahan yang telah diajarkan?

- Apakah soal yang kita susun tidak merupakan pertanyaan yang membingungkan?

- Apakah soal itu tidak sukar untuk dimengerti?

- Apakah soal itu tidak dapat dikerjakan oleh sebagian siswa?

b. Cara kedua adalah mengadakan analisis soal (item analysis). Analisis soal adalah suatu prosedur yang sistematis, yang akan memberikan informasi-informasi yang sangat khusus terhadap butir tes yang kita susun. Dalam hal faedah mengadakan analisis soal:

- Membantu kita dalam mengidentifikasi butir-butir soal yang jelek.

- Memperoleh informasi yang akan dapat digunakan untuk menyempurnakan soal-soal untuk kepentingan lebih lanjut.

- Memperoleh gambaran secara selintas tentang keadaan yang kita susun.

c. Cara ketiga adalah mengadakan checking validitas. Validitas yang paling penting dari tes buatan guru adalah validitas kurikuler. Untuk mengadakan checking validitas kurikuler, kita harus merumuskan tujuan setiap bagian pelajaran secara khusus dan jelas sehingga setiap soal dapat kita jodohkan dengan setiap tujuan khusus tersebut.

\section{Kegunaan Tes Standar Non Standar}

Selanjutnya adalah terkait kegunaan tes standar secara garis besar sebagai berikut:

a) Membandingkan prestasi belajar dengan pembawaan individual atau kelompok.

b) Membandingkan tingkat prestasi siswa dalam keterampilan di berbagai bidang studi untuk individual atau kelompok.

c) Membandingkan prestasi siswa berbagai sekolah atau kelas, dan

d) Mempelajari perkembangan siswa dalam suatu periode atau waktu tertentu.

e) Kelengkapan Tes Standar.

Adapun kegunaan tes non standar secara terperinci sebagai berikut:

a) Untuk menentukan seberapa baik siswa telah menguasai bahan pelajaran yang diberikan dalam waktu tertentu.

b) Untuk menentukan apakah sesuatu tujuan telah tercapai.

c) Untuk memperoleh suatu nilai. 


\section{KESIMPULAN}

Dari berbagai penjelasan di atas maka selaku penulis artikel ini akan memberikan kesimpulan sebagai barikut :

1. Tes standar adalah suatu tes dimana semua siswa menjawab pertanyaan-pertanyaan yang sama dari sebagian besar pertanyaan dikerjakan dengan mengikuti petunjuk yang sama dan dalam batasan waktu yang sama pula.

2. Tes non standar adalah kebalikan tes standar, yaitu tes yang disusun oleh seorang pendidik yang belum memiliki keahlian professional dalam penyusunan tes, atau mereka yang memiliki keahlian tetapi tidak sempat menyusun tes secara baik, mengujicobakan, melakukan analisis sehingga validitas dan reliabilitas belum dapat dipertanggungjawabkan.

\section{DAFTAR PUSTAKA}

Arsi, A., I., \& Arsyam, M. (2021, January 16). Artikel Administrasi Tata Kelola Dalam Pendidikan. https://doi.org/10.31219/osf.io/wsd9r

Janna, N. M., A., kurnia, A. d., \& Arsyam, M. (2021, January 14). Administrasi Keuangan Dalam Pendidikan. https://doi.org/10.31219/osf.io/hmvcf

Arifin, Zainal. (2009). Evaluasi Pembelajaran. Bandung: PT Remaja Rosdakarya.

Muslim, A. Q., \& Wekke, I. S. (2018). Model Penilaian Kinerja Guru. Al-TA'DIB: Jurnal Kajian Ilmu Kependidikan, 11(1), 37-54.

Arsyam, M., \& Alwi, A. M. (2020). MANAJEMEN HIDUP DALAM PERSPEKTIF AL-QUR'AN.

Purwanto, Ngalim. (2006). Prinsip-prinsip dan Teknik Evaluasi Pengajaran. Bandung: PT Remaja Rosdakarya.

Makmur, Z., Arsyam, M., \& Alwi, A. M. S. (2020). Strategi Komunikasi Pembelajaran Di Rumah Dalam Lingkungan Keluarga Masa Pandemi. KOMUNIDA: Media Komunikasi dan Dakwah, 10(02), 231-241.

Baharun, H. (2016). Penilaian Berbasis Kelas pada Pembelajaran Pendidikan Agama Islam di Madrasah. MODELING: Jurnal Program Studi PGMI, 3(2), 204-216.

Ependi, U., Putra, A., \& Panjaitan, F. (2019). Evaluasi tingkat kebergunaan aplikasi Administrasi Penduduk menggunakan teknik System Usability Scale. Register: Jurnal Ilmiah Teknologi Sistem Informasi, 5(1), 63-76.

Arsyam, M. (2020). Manajemen pendidikan islam.

Ependi, U., Putra, A., \& Panjaitan, F. (2019). Evaluasi tingkat kebergunaan aplikasi Administrasi Penduduk menggunakan teknik System Usability Scale. Register: Jurnal Ilmiah Teknologi Sistem Informasi, 5(1), 63-76.

Arsyam, M. (2021). BAHAN AJAR ADMINISTRASI PENDIDIKAN.

Astuti, S. (2016). Penerapan supervisi akademik untuk meningkatkan kompetensi guru dalam menyusun administrasi penilaian di sd laboratorium uksw. Scholaria: Jurnal Pendidikan dan Kebudayaan, 6(1), 117-126. 